\title{
HEAVY METAL DETECTION FROM SEWAGE IRRIGATED SOIL BESIDE RAILWAY TRACKS IN MUMBAI
}

\author{
Alok Gude, $\mathbf{L}$. \\ Department of Botany, St. Xavier's College (Autonomous), Mumbai-400 001. \\ Email: alokgude@gmail.com
}

\begin{abstract}
There are more than 100 local train stations in Mumbai and suburban areas which are connected to each other through railway comprising 4 major lines. Each route contains slow and fast tracks running. On the adjacent side of these routes are small patches of land which are used for cultivation. The railway authorities give these lands for farming of some leafy and non-leafy vegetable crops. Majority of these lands are irrigated by the open sewage lines which run besides and parallel to the railway tracks and they bring many unwanted chemicals which are absorbed by plants to more or less extent. The water in these sewer lines comes from domestic, commercial and other sources. The present study deals with quantification of $\mathrm{Pb}$, $\mathrm{Zn}, \mathrm{Cd}, \mathrm{Hg}$, $\mathrm{Ar}$ and $\mathrm{Cu}$ from soil sample using laboratory methods. The results indicated a low to medium level of pollution of these in soils, except some of the areas where it is high. The $\mathrm{Pb}, \mathrm{Ar}$ and $\mathrm{Cu}$ were common pollutants near many stations and occur in comparable amount whereas $\mathrm{Cd}$ and $\mathrm{Zn}$ occur near fewer stations and also in less to medium quantity and $\mathrm{Hg}$ contents were found to be the least. The results indicate that though the sewage water can be used for such sewage farming, the water quality should be monitored continuously for heavy metals and other form of pollutants to ensure safety for vegetable consumption.
\end{abstract}

Keywords: Heavy metals, Railway tracks, Sewer lines, Sewage farming.

\section{INTRODUCTION}

\subsection{Sewage farming in India}

Scarcity of sewage treatment plants and increasing sewage generation are a big problem for disposal of waste water. In such cases a significant portion of waste water ends up into river basins and is used for irrigation. It is many times bypassed in sewage treatment plants and sold to nearby farmers on charge basis by the Water and Sewerage Board. It has been reported that irrigation with sewage or sewage mixed with industrial effluents results in saving of 25 to 50 per cent of $\mathrm{N}$ and $\mathrm{P}$ fertilizer and leads to $15-25 \%$ higher crop productivity, over the normal waters (Allen, 1973; Henry et al., 1954). In India major crops being irrigated with waste water are cereals, vegetables, flowers, avenue trees, garden plants, fodder crops, agro-forestry plantations and aquaculture (Basta, 1989). In Hyderabad along 10 $\mathrm{km}$ stretch of Musiriver, about 2100 ha land is irrigated with waste water to cultivate paddy. Wheat is irrigated with waste water in Ahmedabad and Kanpur. In New Delhi, various vegetables are cultivated on 1700 ha land irrigated with wastewater in area around Keshopur and Okhla STPs. In Hyderabad, secondary treated wastewater is used to irrigate public parks and avenue trees. In the villages near Hubli-Dharwad in Karnataka, tree plantation is done in similar way. (R. Kaur 1, S.P. Wani, A.K. Singh and K. Lal)

\subsection{Farming beside Railway lines in Mumbai}

The railway network in Mumbai consists of central, western, harbour and trans-harbour lines. The western line runs from Churchgate station to Virar and the central line runs from CST to Kalyan and beyond. The Trans-Harbour lines which connects the central and harbour line and the other line connects vasai road on western line to diva on central line and finally joins the harbour line. The central and the western line have slow train running tracks and also the fast train running tracks. The other lines have only slow train running tracks. On either side of all these tracks are patches of land which are owned by the railways and are given to crop growers for cultivation of various vegetable crops. This was done to promote vegetable cultivation and to protect the railway land against encroachment from slum dwellers. On the side of railway lines are sewage lines which run parallel to the tracks. The sewage lines are open and are cleaned by Municipal Corporation before the rainy season. The sewage lines not only carry sewage but also are meant to carry excess water during heavy rains in the rainy season which would otherwise disrupt the rail services and stop the major mode of transport and commute of local people. The sewage 
in the railway sewage lines comes from the domestic waste of people living nearby. Also the city has number of shops beside the railway lines and also small manufacturing or processing units, slaughter houses, cloth washing units, paints and chemical making and supplying units, printing presses, cars and automobiles repairing shops, construction items suppliers, many residential quarters and complexes and majority of slums. The slums form a big population of the city and have a number of small industries and manufacturing units which manufacture many commodities that are sold in the local market or are sent to other towns and cities. All these constitute the industrial or commercial part which releases their waste, a part of which is released in the railway sewer lines. The farmers use these nearby drains and sewers to as a source of water to supply their farmland needs. They use diesel pumps to draw water from nearby drains to irrigate the farm when there are no rains. The farmers grow crops all year round. They grow vegetables like spinach, radish, fenugreek, lady's finger, red amaranth, and others. The farmers are mostly migrants and live in temporary shelters with their families or with farm workers in the railway farm without any basic amenities like electricity. The farmers use fertilizers, manures and pesticides for their crops. But mostly they depend on the water from sewers beside the railway tracks. The purpose of the study was to check the soil contamination due to waste water usage which contains commercial and domestic wastes. The heavy metals possess variety of toxic effects both on animals and plants.

\subsection{Heavy metals and their affects on humans.}

Arsenic can affect human health and is considered as one of the most significant environmental causes of cancer in the world (Smith et al., 1999; 1997). There is a strong relationship between chronic ingestion of AS and deleterious human health effects. As exposure can occur from food, air and water, but major As poisonings have stemmed from water and this is usually the predominant exposure route. Exposure to As leads to an accumulation of As in tissues like hair, nails, skins resulting in clinical symptoms such as hyperpigmentation and keratosis. There is also an increased risk of skin, internal organ and lung cancers. Cardiovascular disease and neuropathy have also been linked to As consumption. Verbal IQ and long term memory can also be affected, and As can suppress hormone regulation and hormone mediated gene transcription. Increases in fetal loss and premature delivery, and decrease birth weights of infants can occur even at low $(<10 \mu \mathrm{g} / \mathrm{L})$ exposure levels. Chronic As toxicity causes chronic lung disease like chronic bronchitis, chronic obstructive pulmonary disease and bronchiectasis, liver disease like non-cirrhotic portal fibrosis and other diseases like polyneuropathy, peripheral vascular disease, hypertension and ischemic heart diseases, diabetes mellitus, non-pitting edema of feet/hands, weakness and anemia (Guha Mazumder, 2008). Although Cadmium occurs in trace amounts in nature, it has been listed as substance dangerous to environment by WHO because it poses a risk of disturbing the balance of ecosystem along with metals like lead, mercury, copper, zinc, chromium, tin and silver. $\mathrm{Cd}$ is highly stable in environment and is accumulated in soil and living organisms (Terelak et al., 1997). It is easily absorbed by plants, both through their root systems and by leaves, usually to its proportion to its concentration in the environment. Acid reaction of soil increases its mobility and availability (KabataPendias, 1993). Cd remains in the tissues for a relatively long time and is accumulated in vital organs, especially in kidneys and liver. $\mathrm{Cd}$ is extremely toxic metal and has been responsible for many deaths. The symptoms of $\mathrm{Cd}$ poisoning are instantaneous hypertension, shortening of life-span; kidney damage, bronchitis, retardation of growth, gross abnormalities of the vital organs and risk to prostate cancer (Ullah and Enamul Haque, 2010). Zinc interferes with $\mathrm{Cu}$ metabolism. The symptoms of an acute oral $\mathrm{Zn}$ dose may provoke tachycardia, vascular shock, dyspeptic nausea, vomits, diarrhea and pancreatic, and damage of hepatic parenchyma. Although maximum $\mathrm{Zn}$ tolerance for human health has been established for edible parts of crops (20mg/kg) (Long et al., 2003). Elevated levels of Copper in humans are associated with formation of acne, adrenal-cortical hyperactivity, increase in weight of adrenal glands, agoraphobia, hair loss, iron deficiency anemia's, anxiety, arthritis, osteoarthritis, retention of calcium in body, and predisposition of cells to cancerous change. Chronic $\mathrm{Cu}$ toxicity can result in liver disease and severe neurological defect (Janet et al., 2005). Minimata disease due to Mercury poisoning has led to awareness about mercury toxicity. Fetus and children are more susceptible towards mercury toxicity. Mothers consuming diet containing mercury pass the toxicant to fetus and to infants through breast milk. $\mathrm{Hg}$ has been the cause of many disorders including cardiac, reproductive, genetic, nephrological and neurological. Recently heavy metal mediated toxicity has been linked to Alzheimer's, Parkinson's, Autism, Lupus and Amyotrophic lateral sclerosis (Farhana Zahir et al., 2005). Repeated Lead exposures gives rise to abdominal pain, aggressive behavior, constipation, 
sleep problems, loss of developmental skills in children, loss of appetite, fatigue, headaches, irritability, high blood pressure, anemia, kidney dysfunction, numbness or tingling of extremities and memory loss (Patrik, 2006).

These metals can enter the food cycle and food chain by entering into the plants which grow in such soil and finally to humans who consume such vegetables. The knowledge of such effects of heavy metals on humans and other animals and crops led at finding out the rough level of these metals in soil contaminated with sewage water and also at which locations they are above critical level.

\section{METHODOLOGY}

\subsection{Study area}

The area used for the study was the farm patches on western and central railway lines only. The western line starting from Churchgate to Borivali station and the central line starting from CST to Thane station. The western line stations where patches of such farms occur areLower Parel (Lp), Elphistone Road (Er), Dadar (Dr), Matunga Road (Mr), Mahim (Mh), Bandra (Ba), Khar Road (Kr), Santacruz (Sc), Ville Parle (Vp), Andheri (Ad), Jogeshwari (Jo), Goregaon (Gg), Malad (Ml), Kandivali (Kd) andBorivali (Bo). The area beside stations Churchgate, Marine lines, Grant Road, Mumbai Central, Mahalaxmi do not have such farm vegetation. The central line stations beside such sewage farming is done areCurry Road (Cr), Parel (Pr), Dadar (Dr), Matunga (Ma), Sion (Sn), Kurla $(\mathrm{Ku})$, Vidyavihar (Vv), Ghatkopar (Gk), Vikroli (Vk),Kanjurmarg (Ka), Bhandup (Bd), Mulund(Mu) and Thane (Th). The stations on central line where such farming is not done are CST, Masjid, Sandhurst Road and Byculla. Only the stations mentioned above were chosen for the study, the railway line and the associated farms extend far beyond the stations mentioned. The farmlands on harbour and transharbour lines were not included in the study. The farms are actually situated beside the railway lines and spaces between any two stations. Some areas have big farms and some have smaller patches. Three to four soil samples were collected from the bigger vegetation patches in zip lock plastic bags and one soil sample was collected from each of the smaller patch. If the source of water was common, then only two soil samples were collected. The samples were properly labeled using stickers. Survey revealed many vegetable crops which are listed in (Table 1)
The soil collection was conducted from the September 2008 to January 2009 and was part of a minor research project funded by University of Mumbai. The analysis continued till the end of 2010.

Table 1. Vegetable crops cultivated beside railway tracks in Mumbai

\begin{tabular}{|c|c|c|c|}
\hline $\begin{array}{l}\text { S. } \\
\text { No }\end{array}$ & $\begin{array}{c}\text { Marathi } \\
\text { local } \\
\text { Name }\end{array}$ & $\begin{array}{c}\text { English } \\
\text { common } \\
\text { Name }\end{array}$ & Scientific Name \\
\hline \multirow[t]{3}{*}{1} & Palak & Spinach & $\begin{array}{l}\text { Spinaciagleraceae L. } \\
\text { Trigonellafoenum- }\end{array}$ \\
\hline & Methi & $\begin{array}{l}\text { Fenugreek } \\
\text { Green }\end{array}$ & graecum L. \\
\hline & Chawli & amaranth & Amaranthustritis \\
\hline 4 & Ambaadi & $\begin{array}{l}\text { Sorrel } \\
\text { leaves }\end{array}$ & Hibiscus sabdariffa L. \\
\hline 5 & LalMaat & amaranth & $\begin{array}{l}\text { Amaranthuscruentus } \\
\text { L. }\end{array}$ \\
\hline 6 & Bhendi & $\begin{array}{l}\text { Lady's } \\
\text { finger }\end{array}$ & $\begin{array}{l}\text { Abelmoschusesculentus } \\
\text { L. Moench }\end{array}$ \\
\hline 7 & Mula & Radish & $\begin{array}{l}\text { Raphanussativus var. } \\
\text { longipinnatus }\end{array}$ \\
\hline 8 & Alu & Taro & ColocasiaesculentaL. \\
\hline
\end{tabular}

\subsection{Soil samples}

\subsection{Soil treatment}

The soil collected was brought to lab and spread on a tray and was kept for air drying on plastic sheets and metal pans. The different samples collected from the same farm or area or where the source of water was same were mixed together. The roots, stems, stubbles, and bigger stones were removed. The clogs of soil were broken with hand and later pulverized by a circular broad base hammer. The soil was passed through $2 \mathrm{~mm}$ mesh sieve after grinding. The soil was again kept for air drying. The soil was sieved through $0.05 \mathrm{~mm}$ sieve, $1.0 \mathrm{~g}$ soil was weighed and digested with $20 \mathrm{ml} \mathrm{HCl}$ to near dryness. The residue was dissolved in concentrated $\mathrm{HCl}$ and diluted to $25 \mathrm{ml}$. These prepared samples were used first for qualitative analysis of different metals. If the major tests were positive for particular metals, then they were further established for quantitative analysis (Table 2), (Amune et al., 2012; Nagornyy, 2013; Basta, 1989).

Lead- In the alkaline medium, lead reacts with sulphide to form a brown precipitate of lead sulphide. This remains as a fine suspension whose intensity is read on a colorimeter at $440 \mathrm{~nm}$ andis proportional to the amount of lead present in the sample.Standard stock lead solution $10 \mathrm{mg} / \mathrm{ml}$ was prepared by dissolving $13.5 \mathrm{~g}$ of lead acetate in some 
distil water, a drop of acetic acid was added to dissolve it, and the volume was raised to 1 litre with distilled water; standard working lead solution $0.1 \mathrm{mg} / \mathrm{ml}$ was prepared by diluting $1 \mathrm{ml}$ stock solution to $100 \mathrm{ml} .5 \mathrm{ml}$ of sample solution was taken and $2 \mathrm{ml}$ of $1 \% \mathrm{NaOH}$ and $0.5 \mathrm{ml}$ of $10 \%$ sodium sulphide was added, the contents were mixed using cyclomixer and kept standing for 10 minutes. Absorbance was read on spectrophotometer at 440 $\mathrm{nm}$. A series of test tubes with standard working lead solution ranging from $0.0,0.5,1.0 \ldots .5 .0 \mathrm{ml}$ were estimated in the same way (Andrew, 1924; Bennet and Hudson, 1953).

Copper- The citric acid used acts scavenger and chelates out any other metal ions presents. Liquor ammonia serves to maintain $\mathrm{pH}$ at around 10. The copper ions solution forms a straw colored complex with SDDC which is extracted out in organic phase with iso-amyl acetate. Standard stock copper solution $0.1 \mathrm{mg} / \mathrm{ml}$ was prepared by dissolving 251 mg of $\mathrm{CuSO}_{4}$ in some distil water and the volume was raised to 1 litre using distilled water. Standard working copper soln5 $\mu \mathrm{g} / \mathrm{ml}$ was prepared by diluting $5 \mathrm{ml}$ stock solution to $100 \mathrm{ml}$ with distilled water. Carbamate solution $0.1 \%$ was prepared by dissolving $100 \mathrm{mg}$ sodium diethyl dithiocarbamate in $100 \mathrm{ml} 1 \%$ n-butanol. To $5 \mathrm{ml}$ of sample, $1 \mathrm{ml} 15 \%$ Na-citrate buffer, $0.2 \mathrm{ml}$ liquor ammonia and $0.5 \mathrm{ml}$ $1 \%$ sodium diethyl dithiocarbamate (SDDC) were added and volume was made to $6.7 \mathrm{ml}$ with DW. The contents of the test tube were mixed and kept for 10 minutes. Absorbance was read at $440 \mathrm{~nm}$, (Shah and Paul, 1972; Wing, 1982).

Zinc-Zinc-dithizonate complex in aqueous phase in the presence of sodium dodecyl sulphate anionic surfactant.Stock $\mathrm{Zn}$ solution (1g L-1) in $0.0085 \mathrm{M} \mathrm{HCl}$ was dissolved in minimum volume of $1 \mathrm{M} \mathrm{NaOH}$ solution followed by $4 \%$ SDS, finally the solution was acidified with dilute sulphuric acid. To prevent the oxidation of dithizone $0.5 \mathrm{ml}$ of 0.72 molar hydroxylamine hydrochloridewas added and solution was kept at $10^{\circ} \mathrm{C}$. separately SDS $0.6 \mathrm{M}$ was prepared in hot water below $20^{\circ} \mathrm{C}$, sodium acetate $(0.2 \mathrm{M})$ buffer solution was adjusted to $\mathrm{pH} 5$ with acetic acid $(0.2 \mathrm{M})$, sodiumthiosulphate was added to mask interference. The volumes of stock solutions of Zn (II) ion with concentration $3 \times 10^{-6}$ to $1.5 \times 10^{-4} \mathrm{M}$ was used. Dithizone $3.9 \times 10^{-5} \mathrm{M}$ and SDS $1.8 \times 10^{-1}$ M. Absorbance was measured at $535 \mathrm{~nm}$. For sample $5 \mathrm{ml}$ volume was used and added to dithizone and SDS; (Shar and Bhanger, 2001).

Cadmium- Alizarin red S (1, 2-dihydroxy anthraquinone-3sulphonic acid sodium salt) reacts in slightly acidic solution (0.005- $\left.0.05 \mathrm{M} \mathrm{H}_{2} \mathrm{SO}_{4}\right)$ with cadmium to give deep greenish yellow chelate which has absorption maximum of $422 \mathrm{~nm}$ (Terelak et al., 1997).(1.39 x 10-3 Mof Alizarine Red S solution was prepared, cadmium stock solution (1 $\left.\mathrm{mgmL}^{-1}\right)$ was prepared by dissolving $0.228 \mathrm{mg}$ of crystallized cadmium sulfate in deionized water, EDTA $0.01 \%$ $\mathrm{W} / \mathrm{v}$ ) was prepared, a $1 \%$ potassium permanganate solution was also prepared; stock solution of tartarate $(0.01 \% \mathrm{~W} / \mathrm{v})$ was prepared by dissolving $10 \mathrm{mg}$ of potassium sodium tartaratetetrahydrate in $100 \mathrm{ml}$ deionized water; a $100 \mathrm{ml}$ solution of aqueous ammonia was prepared by dilution $10 \mathrm{ml}$ concentrated $\mathrm{NH}_{4} \mathrm{OH}$ (30\% ACS grade) to $100 \mathrm{ml}$ with deionized water. To $0.1-1.0 \mathrm{ml}$ of neutral aqueous with pH-6 solution containing 1-300 $\mu \mathrm{g}$ of cadmium in $10 \mathrm{ml}$ in the flask was mixed with 1:51:110 molar excess (preferably $1.0 \mathrm{ml}$ of $1.39 \times 10^{-1}$ $\mathrm{M})$ of alizarin red $\mathrm{S}$ reagent, which was followed by addition of $1 \mathrm{ml}$ of $0.05 \mathrm{M}$ sulfuric acid (pH 5.5-6.1). The mixture was diluted with deionized water and absorbance was measured at $422 \mathrm{~nm}$; the sample used was $1 \mathrm{ml}$ (Terelak et al., 1997).

Mercury - Diphenylthiocarbazone (dithizone) reacts in slightly acidic $50 \%$ aqueous 1,4 dioxane media (0.18-1.80 M sulphuric acid) with mercury to give an orange chelate which has an absorption maximum at $488 \mathrm{~nm}$. Dithizone $1.56 \times 10^{-3}$ $\mathrm{M}$ solution was prepared by mixing proper amount of diphenylthiocarbazone in known volume of triply distilled 1,4-dioxane. Standard stock mercury (II) solution $4.99 \times 10^{-3} \mathrm{M}$ by dissolving $135 \mathrm{mg}$ of mercuric chloride in de-ionized water. Diluted standard solutions were prepared from this solution. Stock mercury (I) solution was prepared by treating $10 \mathrm{ml}$ of stock mercury (II) solution with few crystals of hydroxylamine hydrochloride in $10 \mathrm{ml}$ dilute sulphuric acid followed by removal of hydrochloride by boiling and dilution with deionized water to 100 ml. A 1\% Potassium permanganate solution was prepared by dissolving in de-ionized water; sodium azide solution $2.5 \% \mathrm{w} / \mathrm{v}$ was also prepared. Tartrate solution $0.01 \% \mathrm{w} / \mathrm{v}$ was prepared by dissolving potassium sodium tartrate tetrahydrate in $100 \mathrm{ml}$ de-ionized water. EDTA solution $0.01 \% \mathrm{w} / \mathrm{v}$ was also prepared by dissolving ethylenediamine-tetraacetic acid, disodium salt dehydrate in $100 \mathrm{ml}$ of de-ionized water. A series of standard solution containing 1-250 $\mu \mathrm{g}$ of mercury (II) in a $10 \mathrm{ml}$ volumetric flask and was mixed with $0.8 \mathrm{ml}$ of $1.45 \times 10^{-3} \mathrm{M}$ of the diphenylthiocarbazone reagent solution followed by the addition $0.1 \mathrm{ml}$ of sulphuric acid (0.45 M). After 1 minute, $5 \mathrm{ml}$ of 1, 4-dioxane was added and the mixture was diluted to the mark with de-ionized 
water. The absorbance was measured at $488 \mathrm{~nm}$ against a reagent blank. The mercury content of sample was found after preparation of calibration graph (Jamaluddin et al., 2003).

Arsenic- Standard arsenic (III) stock solution $1000 \mu \mathrm{g} \mathrm{ml-1}$ was prepared by dissolving $0.1732 \mathrm{~g}$ of $\mathrm{NaAsO}_{2}$ in $100 \mathrm{ml}$ of water. Working standard solution was prepared by dilution of stock solution; $0.4 \mathrm{M}$ hydrochloric acid, 2\% potassium iodate, and $2 \mathrm{M}$ sodium acetate were used. A $0.05 \%$ solution of variamine blue was prepared by dissolving $0.05 \mathrm{~g}$ of variamine blue in $25 \mathrm{ml}$ ethanol and making up to $100 \mathrm{ml}$ with distilled water, the solution was stored in amber bottle. An aliquot of sample solution containing $0.2-14 \mu \mathrm{g} \mathrm{ml-1}$ of arsenic (III) was to $10 \mathrm{ml}$ test tubes, then $1 \mathrm{ml}$ of $2 \%$ potassium iodate and $1 \mathrm{ml}$ of $0.4 \mathrm{M}$ hydrochloric acid were added and the resultant mixture was shaken properly using cyclomix machine. To this $1 \mathrm{ml} 0.05 \%$ variamine blue and $2 \mathrm{ml}$ of $2 \mathrm{M}$ sodium acetate solution was added. The solution was kept for 5 minutes and the volume was made to $10 \mathrm{ml}$ with distilled water. The absorbance was measured at $556 \mathrm{~nm}$ against the reagent blank (Narayan, 2006).

Table 2. Qualitative detection of heavy metals *

(10 $\mathrm{ml}$ of the test solution was concentrated by evaporating on water bath)

$\underline{\text { Lead }}$ Mercury

1. Ts (test solution) + dilHCl - white ppt

2. Ts $+\mathrm{NH}_{3}$ solution - white ppt

3. $\mathrm{Ts}+\mathrm{NaOH}-$ white ppt

4. Ts + dil $\mathrm{H}_{2} \mathrm{SO}_{4}-$ white ppt

5. $\mathrm{Ts}+\mathrm{K}_{2} \mathrm{CrO}_{4} \mathrm{Soln}-$ yellow ppt

6. Ts + KI solution - yellow ppt

7. Ts + Na-sulphite - white ppt

8. $\mathrm{Ts}+\mathrm{Na}_{2} \mathrm{Co}_{3}-$ white ppt
1. Ts + dilHCl - white ppt

2. $\mathrm{Ts}+\mathrm{NH}_{3}$ solution - black ppt

3. $\mathrm{Ts}+\mathrm{NaOH}-$ black ppt may turn yellow.

4. $\mathrm{Ts}+\mathrm{K}_{2} \mathrm{CrO}_{4}-$ red crystalline ppt

5. Ts $+\mathrm{KI}-$ green/ yellow ppt turn red

6. Ts $+\mathrm{Na}_{2} \mathrm{CO}_{3}-$ yellow / reddish ppt

7. $\mathrm{Ts}+\mathrm{Na}_{2} \mathrm{HPO}_{4}-$ white ppt

8. Ts + crystals of ammonium thiocynate + pinch of Co-acetate - blue color.
1. $1 \mathrm{Ts}+\mathrm{NH}_{3}$ soln - blue ppt

2. $\mathrm{Ts}+\mathrm{NaOH}-$ blue ppt

3. Ts $+\mathrm{KI}-$ brown / yellow ppt

4. Ts + ammonium thiocynate - yellow / brown / black ppt
1. $\mathrm{Ts}+\mathrm{AgNO}_{3}-$ yellow ppt

2. $\mathrm{Ts}+\mathrm{CuSO}_{4}-$ green ppt

3. $\mathrm{Ts}+\mathrm{HNO}_{3}$ (boil mixture) $+\mathrm{NH}_{4}-$ molybdate yellow ppt
1. $\mathrm{Ts}+\mathrm{NH}_{3} \mathrm{soln}-$ white ppt dissolves in excess of reagent

2. $\mathrm{Ts}+\mathrm{NaOH}-$ white ppt (insoluble)

3. Ts + HCL - brown ppt
1. $\mathrm{Ts}+\mathrm{NaOH}-$ white gelatinous ppt

2. $\mathrm{Ts}+\mathrm{NH}_{3}-$ white ppt

3. $\mathrm{Ts}+\mathrm{Na}_{2} \mathrm{HPO}_{4}-$ white gelatinous ppt

4. $\mathrm{Ts}+\mathrm{NH}_{4}$-sulphide - white ppt.

Ts $=$ Test solution; $\mathrm{ppt}=$ precipitate

* Vogel's, Quantitative Chemical Analysis- J. Mendham, R.C. Denny, J. D. Barnes, M.J.K. Thoma

\section{RESULTS AND DISCUSSION}

A. The field used for sewage farming was contaminated by various heavy metals to some extent. This was due to the fact that the land is used for cultivation since 1975. Though the metal concentration were within the limits given by Indian safety thresholds (Table 3-4), but the soil concentrations of $\mathrm{Cu}$ exceeded the recommended safety thresholds given by Europe and USA and Canada (Vazhacharickal et al., 2013).
B. The results show that the soil between Lower parel (Lp) and Mahim (Mh) is more polluted by $\mathrm{Cu}$ on the western railway line and also the same but little less near Andheri (Ad) to Borivali (Bo). Similarly on the central line also $\mathrm{Cu}$ is the main pollutant in soil from Curry road (Cr) to Kurla(ku) station and also near Thane (Th) station. On western line, Mahim (Mh) to Ville parle (Vp) and on central line, Sion (Sn) to Ghatkopar (Gk) show high concentration of zinc. This may be due to the fact that this area was clustered with many mills and small industries 
and shops of commerce and industrial peripheral manufacturing units and other supplies. Not only $\mathrm{Cu}$ but these areas have more concentration of all other heavy metals studied than other areas.

C. It is also clear that the areas which are densely populated by human settlements and industries are more polluted by these metals than the areas where population density is less (Sharma et al., 2008).

D. The soil being less contaminated than expected is also due to the fact that the effluent coming from industrial units are finally released in the sea and is then carried away by the waves (Zindge and Govindan, 2000).

E. The majority of crops grown are green amaranth, radish and spinach and these crops absorb more heavy metals. They store an appreciable amount of $\mathrm{Zn}, \mathrm{Pb}, \mathrm{Cu}$ and $\mathrm{Cd}$. The crops are cultivated in the railway fields all year round and therefore may be in a constant process of extraction of these metals (Arora et al., 2008; Intawongse and Dean, 2006).

F. Still it cannot be negated that a number of soil factors and especially $\mathrm{pH}$ plays an important role in making these metals available to plant (Zeng Fanrong et al., 2011).

G. The genetic makeup of plant and the metabolic rate inside, growth rate of plant and the type of storage tissue also has a major role in deciding the absorptive capacity of the plants to such metals. This can lead to removal of some amount of theses metals from soil (Rascio et al., 2011).

H. The presence of heavy metals in soil means that there is presence of these in the sewage water in more amount and they travel to edible plant tissues and may thus affect consumer health.These heavy metals come from factories and other commercial set ups near the sewage supply and these reflect lacking enforcement of existing norms and regulations. However the atmospheric contribution and deposition of heavy metals should also be considered.

I. The sewage water also contains some coliform bacteria which indicates release of animal or human excreta or both in sewage supply channel. Open defecation is commonly seen along railway tracks in Mumbai as there are many slums beside these tracks which lack basic amenities like toilets.
J. The pathogenic microorganisms can stick to green leafy vegetables and may cause diarrhea if the latter are consumed fresh. In India, mostly all the vegetables are cooked and eaten instead of consuming them raw. This practice destroys the pathogenic microorganisms present on the surface of vegetables.

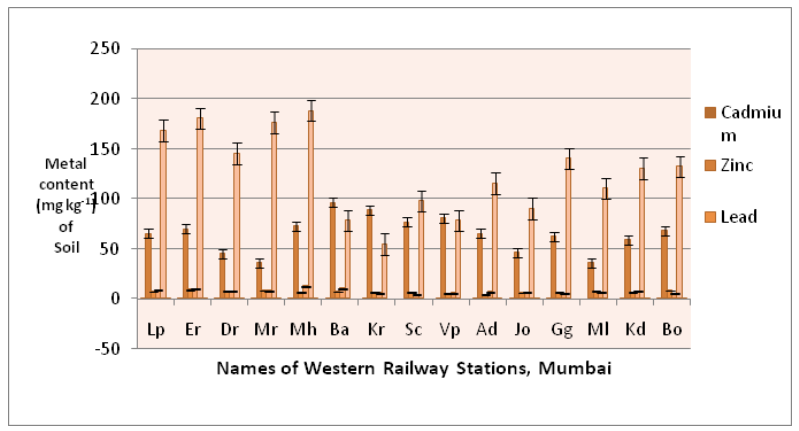

Fig. 1.Distribution of heavy metals in the soil along Western line railway tracks in Mumbai.

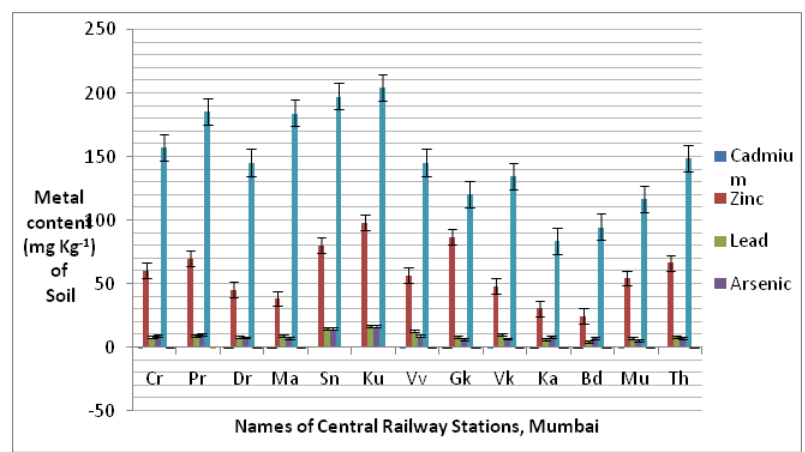

Fig. 1. Distribution of heavy metals in the soil along central line railwaytracks in Mumbai.

K. The farmers also use fertilizers and insecticides in order to maximize yield and also to shorten growing periods by providing optimal nutrient availability. These additional fertilizers and the high nutrient content in sewage water will likely lead to a surplus of available nutrients and possibly ground water pollution. They also use diesel operated pumps for crops growing after monsoon season.

L. The vegetable crops are delivered to local markets and so farmers save on transportation and storage cost. In this the consumer is also benefited and additional jobs are created for street vendors. 
Table 3. Total Cadmium (Cd), Zinc (Zn), Lead (Pb), Arsenic (Ar), Copper (Cu), and Mercury (Hg) concentrations $\left(\mathrm{mg} \mathrm{kg}^{-1}\right)$ in the surface soil $(0-15 \mathrm{~cm})$ of vegetation patches beside Western line railway tracks in Mumbai.

\begin{tabular}{ccccccc}
\hline Data & Cd & Zn & Pb & Ar & Cu & Hg \\
\hline$\underline{\text { Mean }}$ & 0.390667 & 64.61467 & 7.101333 & 7.484667 & 126.0007 & 0.132 \\
$\underline{\text { MD }}$ & 0.25035 & 17.9185 & 1.2409 & 2.18938 & 41.2536 & 0.14967 \\
$\underline{\text { Max }}$ & 0 & 35.7 & 4.24 & 4.44 & 5 & 0 \\
Threshold India* & 0.86 & 96.4 & 9.2 & 12.65 & 188.45 & 0.46 \\
\hline
\end{tabular}

* Awasthi (2007)

Table 4. Total Cadmium (Cd), Zinc (Zn), Lead (Pb), Arsenic (Ar), Copper (Cu), and Mercury (Hg) concentrations $\left(\mathrm{mg} \mathrm{kg}^{-1}\right)$ in the surface soil $(0-15 \mathrm{~cm})$ of vegetation patches beside Central line railway tracks in Mumbai.

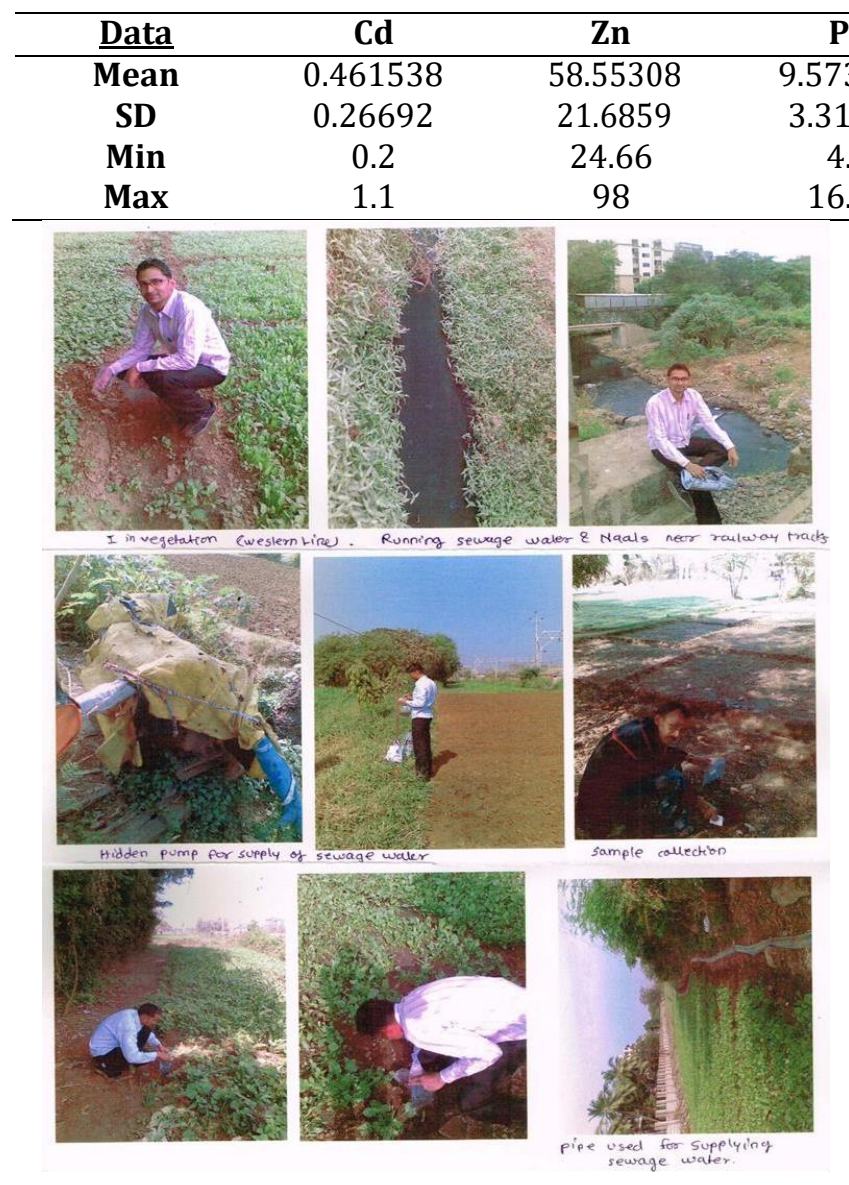

\section{CONCLUSION}

Sewage farming beside railway tracks in Mumbai provide a good source of income to the railways. It offers protection of highly priced land from encroachers and illegal establishments. It also creates employment opportunity and self sustainability to poor farmers, laborers, and benefits consumers. It reduces the some burden of sewage treatment plants. It enables the farmers to grow crops without the use of much fertilizers and manures. It also contributes to greenery and

\begin{tabular}{lccc}
$\mathbf{P b}$ & $\mathbf{A r}$ & $\mathbf{C u}$ & $\mathbf{H g}$ \\
\hline 73077 & 8.962308 & 147.6192 & 0.195385 \\
31972 & 3.15918 & 38.0662 & 0.189 \\
4.8 & 5.84 & 83.5 & 0 \\
6.75 & 16.42 & 204.27 & 0.56 \\
\hline
\end{tabular}

aesthetics and a good landscape for an observer. In order to strengthen the quality of crops the sewage water should be first treated to remove harmful chemicals and metals and then supplied to such fields. Regulations by government for factories, industries, commercial setups, shops and other settlements beside railway tracks should be strictly enforced and certification schemes should be implemented.

\section{ACKNOWLEDGMENT}

I am grateful for the cooperation of the crop growers beside the railway tracks for their support and interaction. I am thankful to the University of Mumbai for financial assistance in form of minor research project. I am also thankful to Mr. NitinLokhande for helping me with the sample collection from the farm lands. I am thankful to then students Candice D'costa, Henrietta Crasto, Milagren Francis, for assisting in some lab work. I am thankful to the timely help and support from the non teaching staff of Botany department of St. Xavier's College. I am also thankful to the general office staff and treasurer office staff with administrative and accounts work, and finally to the Principal Dr. Frazer Mascarenhas S.J. for granting permission for the project and making college infrastructure available for my work.

\section{REFERENCES}

Allen, J. (1973). Sewage Farming: Science races forward to the eighteenth century., Environment: Science and Policy for Sustainable Development, 15:(3) 10. 
Amune, M., Christiana, O. and K. Samuel, (2012). Comparison of Digestion Methods for the Determination of Metal Levels in Soil in Itakpe, Kogi State, Nigeria. Int. J. Pure and Appli. Sci. Tech 13(2): 42-48.

Andrew, R.L. 1924. The colorimetric estimation of Lead in Cream of Tartar. Analyst 49: 129-130.

Arora, M., Kiran, B., Rani, S., Rani, A., Kaur, B. and N. Mittal, (2008). Heavy metal accumulation in vegetables irrigated with water from different sources. Food Chemistry 111(4): 811-815.

Basta, N.T. 1989. Determination of metals in soils and sewage sludges by ion chromatography and the effect of cropping systems on metal adsorption by soils.

Bennet, A. and J.R. Hudson, (1953). Lead determination, Modified dithizone procedure for determination of Lead in Beer. Brewing Industry Research Foundation, 59: 137.

Farhana Zahir., Shamim J. Rizwi., Soghara K. Haq and Rizwan H. Khan, (2005). Environ. Tox. Pharmacol 20(2): 351-350.

Guha Mazumder, D.N. (2008). Indian J Med Res 128: 436-447.

Henry, C.D., Moldenhauer, R.E., Engelbert, L.E. and E. Truog, (1954). Sewage effluent disposal through irrigation. Sewage and Industrial Wastes 22(22): 123-135.

Intawongse, M. and J.R. Dean, (2006). Uptake of heavy metals by vegetable plants grown on contaminated soil and their bioavailability in human gastrointestinal tract. Food Additives and Contaminants 23(1): 36-48.

Jamaluddin Ahmed, M. and Md. Shah Alam, (2003). A rapid spectrophotometric method for the determination of mercury in environmental, biological, soil and plant samples using diphenylthiocarbazone. Spectroscopy, 17: 4552.

Janet Y. Uriu-Adams and Carl L. Keen, (2005). Molecular Aspects of Medicine 26(4-5): 268-298.

Kabata-Pendias, A. (1993). Biogeochemiapierwiasktkowsladowych, Wyd. Geologiczne, Warszawa.

Long, X.X., Yang X.E.., Ni W.Z., Ye Z.Q., He Z. L., Calvert D.V. and J.P., Stoffella, (2003). Communications in Soil Science and Plant Analysis, 34(9and10): 1421-1434.
Nagornyy, V.D, (2013). Soil and Plant Analysis Textbook, Moscow.

Narayan, B., Tom Cherian, Mendalain Mathew and Chand Pasha, (2006). Indian J. Chem. Tech 13: 36-40.

Patrik, L. (2006). Alternative Medicine Review. J. Clini. Therapeu 11(1): 2-22.

Rascio Navari-Izzo, F. (2011). Heavy metal hyperaccumulating plants: How and why do they do it? And what makes them so interesting? Plant Science 180(2): 169-181.

Shah, S.M. and J. Paul, (1972). Simultaneous determination of copper and manganese with sodium diethyl dithiocarbamate. Microchemical Journal 17(1): 119-124.

Sharma, R.K., Agrawal, M. and F.M. Marshal, (2008). Atmospheric deposition of heavy metals $(\mathrm{Cu}$, $\mathrm{Zn}, \mathrm{Cd}$, and $\mathrm{Pb}$ ) in Varanasi City, India. Environmental Monitoring and Assessment 142(1): 269-278.

Smith, A.H., Hopenhayn-Rich., Bates, M.N., Goeden, H.M., Hertz-Picciotto, I., Duggan, H.M., Wood, R., Kosnett, M.J. and M.T. Smith, (1999, 97). Env. Health Perspect. 259-267.

Terelak, H., Stuczynski, T., Motowickaterelak, T. and M. Piotrowska, (1997). Arch. Ochr. Srod 23:167.

Ullah, M.R. and M. EnamulHaque, (2010). J. Chem. Eng 25(1): 10.

Vazhacharickal, P.J., Predotova, M., Chandrasekharam, D., Bhowmik, S. and A. Buerkert, (2013). Urban and peri-urban agricultural production along railway tracks: a case study from the Mumbai Metropolitan Region. J. Agri. Rural Develop. Trop. Subtrop 114(2): 145-157.

Wing, R.E. and W.E. Rayford, (1982). Heavy Metal Removal using Dithiocarbamate.

Zeng Fanrong, Ali, S., Zhang, H., Quyang, Y., Qiu, B., $\mathrm{Wu}, \mathrm{F}$. and G. Zhang, (2011). The influence of $\mathrm{pH}$ and organic matter content in paddy soil on heavy metal availability and their uptake by rice plants. Environ. Pollut 159(1): 84-91.

Zindge, M.D. and K. Govindan, (2000). Health status of Coastal waters of Mumbai and regions around., Environmental Problems of Coastal areas in India, (eds.), by Sharma, V.K, , pp. 119132. 